\title{
Sharia Supervisory Board, Audit Committee, and Corporate Social Responsibility Disclosure
}

\author{
Astuti Dola Bastina and Yustrida Bernawati \\ Faculty of Economic and Business, Universitas Airlangga, Surabaya \\ Email: Adbastina93@gmail.com
}

\begin{abstract}
This study examined the influence of the Sharia Supervisory Board and Audit Committee on the corporate social responsibility disclosure. The research sample used in the study is Islamic Banks in Indonesia from 2014 to 2018, with a total of 60 banks. Quantitative methods with multiple linear regression data analysis techniques were used in this study. The testing of hypotheses uses Ordinary Least Square (OLS) regression with a significance of $1 \%, 5 \%$, and $10 \%$. Test $\mathrm{F}$ shows a model that stable and significant. The results of this study supported the research hypothesis that ACSIZE brought a positive and significant effect on corporate social responsibility disclosure. In addition, the sharia supervisory board and the audit committee meet not influence the corporate social responsibility disclosure.
\end{abstract}

Keywords: Sharia Supervisory Board, Audit Committee, Islamic Social Responsibilty, Return on Asset, Audit Quality.

\section{INTRODUCTION}

The more important aspects of the corporate culture are corporate social responsibility (Bereskin et al., 2018). For two decades last, CSR has become public attention, academic, and management because of an increase in social activism and the number of companies that have been unsuccessful (Appuhami and Tashakor, 2017; Fernández et al., 2018). The company has to know to the balance between the purpose of both financial and non-financial to express the report that deals with economic performance, of environmental and social problems the company (Birindelli et al., 2015; Fernández et al., 2018). According to (Purwanto, 2011), the company must be responsible for expressing the impact of the activities carried out by that does not merely to the stakeholders as well, but also must have a moral responsibility to the environment, labor, and the surrounding community. Government Regulation No. 47 of 2012 on Social and Environmental Responsibility of Limited Liability Company. A government regulation about the responsibility of corporate social suggests business operation companies should align with the interests of stakeholders (Ernawan and Daniel, 2019)

The quality of corporate social responsibility (CSR) disclosure in Indonesia is still low (CNN, 2016). It was because that several parties are still opposed to a legal obligation on the concept of CSR that is held in opposition with some of the articles of the Indonesian constitution, namely art 28d paragraph (1), art 28i clause 2, and article 33 paragraph 4) different of the Indonesian constitution with the concept of the CSR in various a foreign country, especially developed countries, where CSR is considered as a concept that is the 
ethical and moral infinite-dimensional so the implementation of this still is voluntary in nature not as a legal duty. Many cases companies that do not realize CSR is one of the main impacts. One of which is some companies banks in West Pasaman district, west Sumatera allegedly not realize CSR to public funds, such as Bank Nagari, Bank Nagari Syariah, Bank BNI, Bank BNI Syariah, Bank Danamon, Bank Mandiri, Bank Mandiri Syariah, and Bank BRI because the company consider CSR only burden the company double in the obligation of paying taxes and CSR costs (Source: Antaranews.com).

The low quality of the corporate social responsibility disclosure in Indonesia was due to several factors influence it, one of them is corporate governance (CG) (Rahman and Bukair, 2013). Effectiveness of governance affects the quality involved in applying the Syariah and meet the expectations of people especially the Muslim community to provide based bank Syariah (Hameed et al., 2003). (Hameed et al., 2003) also stated that CG can develop the Syariah financial institutions to the community and ensure that their businesses do not have any negative impact on the environment and people in around it. It is associated with the function of the mandate as the core of $\mathrm{CG}$, which means the company was given a trust to manage its resources efficiently and effectively. If not, $\mathrm{CG}$ the weak can affect the quality reporting and disclosure.

In addition to the development of research into the activity of the social responsibility disclosure, according to Islamic finance country index (IFCI 2019), banking and financial institutions this year edition revealed that Syariah banks in Indonesia ranked first with points index 81,93 edged ahead of Malaysia who dominated the index since 2011. Formerly, Islamic banking in Malaysia ranked in number one for three consecutive years, shift from Iran in 2016. Now, Indonesia has jumped five places to reach the top slot this year.

Previous studies have noted the need for the CSR disclosure in sharia different with the conventional practice of social responsibility, to provide us with information about its liabilities and the responsibility of conforming to Islamic law, that it demands information about zakat, alms, and activities environment protection (Othman and Thani, 2010). In your sphere of Amanah, Business entities must have the responsibility of the owner or stakeholders. In addition in Syariah, all the transactions that Islam could be construed as usury, obscurity (gharar), fraud, stockpiling and manipulation of the price (Che Azmi et al., 2016). Previous studies have identifying characteristics of the governance arrangements as the main factors that have an impact on corporate social reporting, but the survey relatively little done in the context of Islamic social reporting. Islamic social reporting is the expansion of reporting responsibility social include Islamic values in it (Othman and Thani, 2010).

The framework of the theory legitimacy adopted to understand the extent to which the characteristics of corporate governance influence response to the company against various groups of the stakeholders (Khan et al., 2013). According to (Wijaya, 2012) in expressing awareness of corporate social responsibility should be based on the notion that economic and valid but has an obligation to stakeholders, the company also has an obligation to group or person having an interest both inside and outside the company. The CSR disclosure aims as the evaluation and communication with stakeholders.

Researchers have conducted a study on disclosures empirical social responsibility in the Islamic bank, among others are (Farook et al., 2011; Hassan and Syafri Harahap, 2010; (Mallin et al., 2014; Nugraheni and Khasanah, 2019; Rahman and Bukair, 2013). (Farook et al., 2011); (Rahman and Bukair, 2013) identify the influence of the characteristics of sharia supervisory board (SSB) the CSR disclosure which is focusing that in the next five 
an attribute, which is the number of SSB, cross membership, doctoral qualification, the reputation, and the expertise of SSB. The results show that a combination of the characteristics of the Syariah supervisory board to depend on CSR disclosure Islamic bank. Different the result of (Farook et al., 2011); (Rahman and Bukair, 2013), the next research done by (Khoirudin, 2013); (Nugraheni and Khasanah, 2019) which test the influence of characteristics of the sharia supervisory board, the results show that size and qualifications the syariah supervisory board not proved had an influence of CSR disclosure.

(Appuhami and Tashakor, 2017); (Jizi et al., 2014); (Kent and Stewart, 2008) examined characteristics of audit committee against of the corporate social responsibility disclosure, results showing that companies with greater audit committee effective in the responsibility of monitoring and reporting, so as to increase the disclosure of CSR, in addition, the audit committee meeting also shows that a meeting which is more often tending to find differences and improve the disclosure of CSR. But the different research indicated by (Katmon et al., 2019) audit committee size will increase the quality of CSR because the management audit committee can help in providing information on, higher quality the audit committee meeting and have no influence on CSR. While research (Bicer and Feneir, 2019) the results show that characteristic audit committee, as measured by the size and frequency of meeting them will not affect the CSR disclosure.

Research that examined the influence of the Syariah supervisory board and the audit committee for the corporate social responsibility disclosure still inconclusive. Therefore, this study wanted to test further influence shariah supervisory board against the corporate social responsibility disclosure. The population research is Islamic Banks in Indonesia. The purpose of this research is to test the influence of the shariah supervisory board and audit committee variables on corporate social responsibility disclosure. Therefore, the data analysis technique used is the model of multiple regression with STATA 14. This research will contribute to the development of the theory accounting especially with regard to the corporate social responsibility disclosure.

\section{THEORETICAL REVIEW}

Legitimacy theory. The theory of legitimacy said that the organization is constantly trying to make sure that they are doing activities in accordance with a definition and norma-norma a society where they are. Legitimacy can be considered as equalize perception or the assumption that an action was taken by an entity is the desired action, deserve to or in accordance with norms, system the value of, trust and a definition that developed socially (Suchman, 1995)

(Haniffa and Cooke, 2002) in the theory of legitimacy, the company had a contract with the community to undertake work based on the values of justice, and how the company responded to an interest group to a company of making a legitimate claim. Hence the company improves faith that concerns only the survival of the company is also hanging from a relationship between companies and the community and an environment in which the company running its activities. It does not happen misalignment where the values of a company with the value of the community, so the company would be lost its legitimacy which would have an impact on the survival of the company.

The underlying of theory legitimacy is the contract happening in the society between the company with the communities of which the company is operating and use up economy 
explained pertaining to the force of the theory legitimacy in assuming this responsibility company corporate social there are two important to the developing country: (1) Capability to establish a motive optimization was the profit-making a much more clear about the motivation enterprise to enlarge his social responsibility, (2) Cultural factors of legitimation organization can be forming the different institutions in different contexts.

According to an explanation, the theory of legitimacy is one of the theories underlying the corporate social responsibility (CSR) disclosure to ensure the responsibility of going well and disclosure CSR would be overseen by Syariah supervisory board. Basically, the corporate social responsibility disclosure aimed to show to the community social activities behavior by the association and its effect on the community. Seen from one side, this purpose has good. CSR useful for showed that the company is exertion and performing in line with expectations of society, one of the tasks of the audit committee is to ensure that and think about how to do we obedient company with the quality of CSR disclosure. So this study saw how characteristics Syariah supervisory board and audit committee on corporations to improve the quality of the disclosure of CSR.

Stakeholder theory. The theory stakeholders said the company is not an entity that is only operational for its own sake but had to benefit its stakeholder. Definition stakeholders floated (Kasali, 2006) is any group of people both be inside both firms and out companies that had a role in the successful company. Thus, the existence of a company is strongly influenced by support provided by stakeholders with this enterprise because of that an enterprise is strongly influenced by support provided by stakeholders to the company (Fatoni et al., 2016). Basically the responsibility of the company whereabouts of limited to maximize profit in the interest of shareholders but more broadly in this regard to create for the interests of the stakeholder's welfare is that all parties have an of the company.

The existence of this theory stakeholders in a company is expected to benefit stakeholders. These benefits are can be given by means of applying corporate social responsibility (CSR), the company is expected to the program would increase the welfare of laborers, customers, and locals. So that it could be promoted a good relationship between the company and the environment where it operates. (Clarkson, 1995) proposed the theory stakeholders to analyze and evaluate because it involves the role of CSR management in an effective disclosure. While (Omran and Ramdhony, 2015) mentioned that the theory stakeholders suitable for an organization that operates in developing countries (like, Indonesia). The important task of management is protecting the interests of stakeholders guarantee them that the management will make decisions that benefit everyone.s

The implications of the theory stakeholders is a company to an end of his organization had to account for all stakeholders, whether it is an employee, the government, shareholders, and lain-lain. So one of the means to account for its performance through, CSR showing activity the firm operations to the stakeholders. Characteristics of the Syariah supervisory board and audit committee must ensure that the company did CSR disclosure with good and right.

\section{Hypothesis}

The influence of the shariah supervisory board characteristics on CSR disclosure. Financial services authority regulation no 1 / POJK.03 / 2019 on the establishment of 
implementation guidelines for the work and the Syariah supervisory board explained that one of the tasks of the audit committee is to supervise the activities of banks to fit with the Syariah principle. This indicates that the Syariah supervisory board having a share in terms of making sure the disclosure of social responsibility to be issued by a company to external users. In addition, the audit committee also has a duty to oversee the work of the auditors to produce external audit quality. To meet goals the Syariah supervisory board was needed in order for the Syariah supervisory board effective from the point of view of attributes that is with the Syariah supervisory board. Those attributes based on research conducted by (Rahman and Bukair, 2013) is the number of SSB member, cross membership, doctoral qualification, and expertise of SSB member.

The previous study has shown that characteristic of the Syariah supervisory board has had a positive impact on the disclosure of corporate social responsibility, means thus are getting better board of trustees its syariah, so the disclosure of it is also are getting better. This is also performed by (Farook et al., 2011); (Rahman and Bukair, 2013), thus hypothesis advanced by namely:

H1: Characteristics of the Syariah supervisory board had an influence on the CSR disclosure

The influence of the Audit Committee size on CSR disclosure. The audit committee size (AC) referring to a number of members in place thus the audit committee. According to a letter of recommendation ASX 4.2 (2010), AC must have at least three members to make sure he has skill adequate to undertakes responsibility monitoring and reporting a committee as CSR disclosure. AC needs resources director in terms of the director and their tenure in committee to allow them performing a role effective monitoring and improve of CSR disclosure (DeFond and Francis, 2005; Mangena and Pike, 2005).

The larger audit committee has the 'necessary strength, diversity of expertise and views to ensure proper monitoring' which leads to CSR disclosure (Bédard et al., 2004). However, there are additional costs associated with large committees such as the potential costs of poor communication, coordination, and control (Jensen, 1993). The study also believes that larger committees can suffer from problems of free riders and scattered responsibilities, which can damage CSR disclosure practices (Li et al., 2012; Mangena and Pike, 2005). This seems to indicate that companies must consider the additional costs and benefits associated with $\mathrm{AC}$ in increasing the size of the $\mathrm{AC}$ to increase disclosure. While the best AC size can vary from company to company depending on factors such as company size and nature of operation, the size of the air conditioner in general should not exceed five members (Arthur Andersen, 1998) or six (National Association of Company Directors (NACD, 2000).

Empirical evidence about the relationship between AC size and disclosure tends to represent limited and mixed CSR disclosures. For example, (Li et al., 2012), using 100 companies registered in the United Kingdom, found a positive relationship between AC size and intellectual capital disclosure. Similarly, the study found that AC size was positively related to earnings management (Cornett et al., 2009). In contrast, other studies found no evidence between AC size and voluntary disclosure (Mangena and Pike, 2005) or earnings management (Bedard et al., 2004). Given these various theoretical findings and arguments, this research makes the hypothesis that:

H2: Audit Committee size had an influence on the CSR disclosure 
Influence of frequency of audit committee meetings on CSR disclosures. The frequency of meetings refers to the number of meetings held by the audit committee (AC) per budget year. According to ASX guidelines (ASX, 2010), the audit committee must meet often enough to carry out its role effectively. The Financial also noted that 'Audit committee formal meetings are at the heart of its work' and 'Sufficient time must be allowed to allow the audit committee to conduct full discussion as needed'. Although there is no agreement on the optimal number of AC meetings, some professional audit firms such as Price (Waterhouse, 1993) and (KPMG, 1999) recommend a minimum of three or four meetings per year.

Basically, Acs that often meet every year are more likely to find differences and ensure the reliability of the CSR disclosure process. Frequent meetings also help members to stay informed and be proactive about issues related to CSR disclosure. That the frequency of AC meetings allows directors more time to effectively carry out monitoring roles and increase corporate disclosures such as CSR. Likewise, Acs that hold meetings can often resolve disclosure issues related to accounting, auditing, and CSR in a timely manner. Empirical findings also show a positive relationship between $\mathrm{AC}$ frequency and disclosure (financial and non-financial). For example, (Li et al., 2012), using 100 companies registered in the $\mathrm{UK}$, found a positive relationship between the frequency of $\mathrm{AC}$ meetings and the level of IC disclosure. Likewise, in an examination of 248 companies registered in the US, that the frequency of AC meetings positively affected the disclosure of internet finance. Furthermore, the frequency of AC positively affected the level of financial disclosure of Spanish companies. This empirical finding implies that Acs that meet more often are better able to identify CSR activities and disclose CSR activities in the company's annual report. Therefore, this study hypothesizes that:

H3: The frequency of Audit Committee meetings has an effect on CSR Disclosures

\section{METHODOLOGY}

This study aims to test the influence of the Syariah supervisory board, size and frequency of committee meeting the audit for the disclosure of CSR through the testing of hypotheses. Hence, the research methodology used in this research is research quantitative. The kind of data that used in this research was secondary data that is the data collected in the form of so, have been pooled and processed by the other hand. Secondary data used in this research was the annual report general sharia-based bank in Indonesia in accordance with sample criteria in this research 2014-2018 year.

The measurement of corporate social responsibility is measured using the Syariah banking ssbscore of the index Islamic social reporting (ISR). An index that used in research refers to the children that has been modified by (Othman and Thani, 2010) with some adjustments developed that can be seen in appendix 1 . With content, analyze each category but we made in research instruments 1, expressed if given a score of to the annual report, and 0 if not disclosed. We have been made so calculated as follows:

\section{Disclosure Level $=$ Number of complied level/Maximum Total Score}

In this study three independent variables were used, namely: The effectiveness of the Sharia Supervisory Board (size, dual-position, educational background, and expertise) and 
the audit committee, namely: the size of the audit committee and the frequency of audit committee meetings. The characteristics of DPS can be measured by calculating the overall score to take the total effect of the existence of DPS and its effectiveness with SSBSCORE, where the number of DPS is measured by the perfect number of DPS members between 23 to the reporting period using a nominal scale. Dichotomous; 1 for banks with 3 or more members and 0 if less than 3. Double DPS positions are measured on a nominal scale where 1 if DPS members have dual positions, and 0 if they do not have. Doctoral qualifications in economics and business using a nominal scale where 1 for DPS with graduates in economics and business, while 0 for DPS who do not have a background in economics and business graduates. SSB expertise is measured by 1 if SSB members have knowledge and experience in accounting and finance, and 0 if they don't have.

The next measurement of the characteristics of the sharia supervisory board is to calculate the overall score to take the total effect of the existence of the sharia supervisory board (SSB) and its characteristics. The score summarizes the dichotomous characteristics of SSB, namely the number of members, the presence of members with multiple positions, doctoral qualifications and from the leading scholars who lead the board and SSB expertise. Calculating Sharia Supervisory Board scores are as follows:

SSBSCORE $=$ NSSB+CROSS+ PHD+ESSB
Where:
$\begin{array}{ll}\text { SSBSCORE } & : \text { the score of SSB (NSSB + CROSS +PHD + ESSB) } \\ \text { NSSB } & : \text { the number of SSB } \\ \text { CROSS } & : \text { the SSB board having at least one (1) of them with duality jobs } \\ \text { PHD } & : \text { the SSB having at least one }(1) \text { of them with Ph.D } \\ \text { ESSB } & : \text { the SSB consisting having at least one (1) of them with experience } \\ \text { and knowledge in the field of Islamic Bank }\end{array}$

The size of the audit committee measured by the number of members of the audit committee.The number of audit committee meeting measured by the number of the meeting run by the audit committee which has already joined the organization to an enterprise per year. The disclosure of the responsibility of social companies did not only influenced by the Syariah supervisory board and audit committee. Hence, three large control was used in the study. Control is the independent variable that has been having an effect on the dependent variable, namely the disclosure of CSR.

The population in this research are the Islamic Banks in Indonesia of 12 companies of 2014-2018. Company Syariah commercial banks selected as the population research because the company operating Syariah banking deals that CSR of Syariah.

The data collection method used in this research is a method of documentation by downloading the company's annual report available on the website company. The necessary data to the annual report is the number of SSB, cross membership, doctoral 355lamos355cation of SSB, expertise of SSB, the size of audit committee, the frequency of audit committee meeting, the size of the company, the company performance, the quality of audit and social aspects of the disclosure of the responsibility of the company. Multiple regression to assay statistics that saw the value statistic from the results of this research is using an instrument in the form of testing STATA. 
Linear regression analysis multiple was chosen because the number of the independent variables in this study was more than one. Multiple regression used to test hypotheses. As for regression models being used is as follows:

$$
\begin{aligned}
& I S R=\beta_{0}+\beta_{1} \text { SSBSCORE }+\beta_{2} A C S I Z E+\beta_{3} A C M E E T+\beta_{4} F S I Z E+\beta_{5} A Q+\beta_{6} \\
& A Q+\varepsilon
\end{aligned}
$$

Where:

$\begin{array}{ll}\text { SSBSCORE } & : \text { the score of SSB (NSSB + CROSS +PHD + ESSB) } \\ \text { NSSB } & : \text { the number of SSB } \\ \text { CROSS } & : \text { the SSB board having at least one (1) of them with duality jobs } \\ \text { PHD } & : \text { the SSB having at least one (1) of them with Ph.D } \\ \text { ESSB } & \begin{array}{l}: \text { the SSB consisting having at least one (1) of them with experience } \\ \text { and knowledge in the field of Islamic Bank }\end{array} \\ \text { ACSIZE } & : \text { the number of audit committee } \\ \text { ACMEET } & : \text { frequency of audit committee meetings } \\ \text { FSIZE } & : \text { Logaritma natural of total asset } \\ \text { ROA } & : \text { Return on Asset } \\ \text { AQ } & : \text { Auditor size with Big } 5 \\ \text { ESSB } & : \text { Efektivitas SSB (SSB + NSSB + CROSS + PHD +ESSB) } \\ \beta_{3,}, \beta_{4}, \beta_{5}, \beta_{6} & : \text { koefisien regresi parsial }\end{array}$

Statistical Test Results. Based on table 1, the total number of samples in this study is 60 observations, in this study shows that the maximum value of SSBSCORE in the company structure is 4 and the minimum value is 2 with an average value of 2.983333 . The Audit Committee Size (ACSIZE) variable has a maximum value of 7 and a minimum value of 2 with an average value of 3.95. The Audit Committee Meet variable has a maximum value of 31 and a minimum value of 4 with an average value of 1.141667 . The company size variable has a maximum value of 3,299485 and a minimum value of 27,2184 with an average value of 2,996308. ROA has a maximum value of 0.0802 and a minimum value of -0.1689 with an average value of 0.002585 . Audit Quality has a maximum value of 1 and a minimum value of 0 with an average value of 0.6333333. For Islamic Social Reporting Disclosure (ISR) has a maximum value of 54,331 and a minimum value of 27,318 with an average value of 3.707622 .

Table 1. Descriptive statistics of research variables

\begin{tabular}{lccccc}
\hline \multicolumn{1}{c}{ Variable } & Obs & Mean & Std. Dev. & Min & Max \\
\hline & & & & & \\
ISR & 60 & 3.707622 & .5994923 & 27.318 & 54.331 \\
SSBSCORE & 60 & 2.983333 & .7700246 & 2 & 4 \\
ACSIZE & 60 & 3.95 & 1.294382 & 2 & 7 \\
ACMEET & 60 & 1.141667 & 5.412765 & 4 & 31 \\
FSIZE & 60 & 2.996308 & 1.391194 & 27.2184 & 3.299485 \\
\hline
\end{tabular}




\begin{tabular}{lllccc}
\hline ROA & 60 & .002585 & .0360638 & -.1689 & .0802 \\
AQ & 60 & .6333333 & .4859611 & 0 & 1 \\
\hline
\end{tabular}

Source: (Data research, 2019)

In the results of table 2 displays the Pearson correlation matrix to determine the strength of the relationship between variables. SSBSCORE has a positive and significant correlation of $1 \%$ with ISR. The SSBSCORE variable has a correlation value of 0.368 and a significant value of 0.004 . ACSIZE has a correlation value of 0.523 and a significant value of 0.000 . FSIZE has a correlation value of 0.449 and a significant value of 0.000 . AQ has a correlation value of 0.175 and a significant value of 0.020 . These results indicate that the SSBSCORE, ACSIZE, FSIZE, and AQ variables have a strong correlation with ISR.

Table 2. Pearson's test correlation of research variables

\begin{tabular}{|c|c|c|c|c|c|}
\hline Variable & Obs & Mean & Std. Dev. & Min & Max \\
\hline ISR & 60 & 3.707622 & .5994923 & 27.318 & 54.331 \\
\hline SSBSCORE & 60 & 2.983333 & .7700246 & 2 & 4 \\
\hline ACSIZE & 60 & 3.95 & 1.294382 & 2 & 7 \\
\hline ACMEET & 60 & 1.141667 & 5.412765 & 4 & 31 \\
\hline FSIZE & 60 & 2.996308 & 1.391194 & 27.2184 & 3.299485 \\
\hline ROA & 60 & .002585 & .0360638 & -.1689 & .0802 \\
\hline AQ & 60 & .6333333 & .4859611 & 0 & 1 \\
\hline
\end{tabular}

Table 3 presents the results of OLS (Ordinary Least Square) Corporate Governance, Sharia Supervisory Board Effectiveness (SSBSCORE), Audit Committee Size (ACSIZE) and Audit Committee Meeting Frequency (ACMEET) on Islamic Social Reporting (ISR) with additional control variables, Firms Size (FSIZE), Return on Assets (ROA), and Quality Audit (AQ). In the OLS regression model, the independent variable is able to explain the dependent variable by 0.4280 or by $42.80 \%$, while the remaining $57.20 \%$ can be explained outside the research variables such as environmental performance, environmental committee, and sustainability committee. The normality test in the regression model shows that above the 5\% significance level of 0.6169 and it can be concluded that the research data is normally distributed.

In accordance with previous findings, estimating that companies that have more audit committee members have a positive relationship with disclosure of corporate social responsibility, can be seen in table 3 . We find that the ACSIZE positive coefficient is 0.1764261 and is significant at the $5 \%$ level $(\mathrm{t}=1.98)$. This finding shows that $\mathrm{H} 2$ is accepted, a larger number of audit committee members helps management in providing higher-quality information, offers more experience and knowledge, which in turn strengthens corporate governance and managerial ability to make better business decisions to improve governance corporate governance (Appuhami \& Tashakor, 2017; Katmon et al., 2019). 
It can be concluded that this might indicate that the number of audit committee members plays an important role in the company to determine the disclosure policy of corporate governance as well as being an effective volunteer at Islamic banks in Indonesia, as they strive to achieve transparency to their stakeholders and the number of members Larger audit committees have a stronger tendency to deal with issues related to corporate governance, the results of this study are in accordance with (Appuhami and Tashakor, 2017); (Katmon et al., 2019).

Table 3. Results of OLS Regression

\begin{tabular}{|c|c|c|c|c|}
\hline \multirow[t]{2}{*}{ Variable } & \multicolumn{4}{|c|}{ Islamic Social Reporting } \\
\hline & Coef. & Std. Err. & $\mathbf{T}$ & $\mathbf{P}>\mathbf{t}$ \\
\hline _cons & -1.499924 & 1.554068 & -0.97 & 0.339 \\
\hline SSBSCORE & .1116696 & .1032496 & 1.08 & 0.285 \\
\hline ACSIZE & .1764261 & .089095 & 1.98 & $0.053^{*}$ \\
\hline ACMEET & .0076407 & .0174972 & 0.44 & 0.664 \\
\hline FSIZE & .1417756 & .0533619 & 2.66 & $0.011^{\text {*** }}$ \\
\hline ROA & -1.14116 & 1.99033 & -0.57 & 0.569 \\
\hline $\mathbf{A Q}$ & .0205017 & .1967939 & 0.10 & 0.917 \\
\hline $\mathbf{N}$ & 60 & & & \\
\hline $\mathbf{F}$ & 0.0011 & & & \\
\hline $\mathbf{R}^{2}$ & 0.4280 & & & \\
\hline Normality & 0.6169 & & & \\
\hline Year Dummies & Included & & & \\
\hline
\end{tabular}

The regression results on the sharia supervisory board characteristic variable showed a positive coefficient of sharia supervisory board value of 0.1116696 and not significant $(t$ $=1.08$ ) and the coefficient of the number of audit committee meetings (ACMEET) was positive 0.0076407 and not significant $(\mathrm{t}=0.44)$. This finding shows that $\mathrm{H} 1$ was rejected because there are certain factors or situations. According to the data from this study, according to the (Nugraheni and Khasanah, 2019), the majority of SSB members have expertise in one field of science, namely muamalah. Such expertise can have an impact on the nature of SSB to better control the operations and products issued by Islamic banking rather than CSR disclosure. Thus, the sharia supervisory board cannot play a maximum role in improving corporate governance practices such as supervision within the company.

Audit Committee Size (ACSIZE) shows a positive coefficient of 0.1764261 and is significant at the $5 \%$ level $(\mathrm{t}=1.98)$. This means that the relationship between AC size and disclosure tends to represent CSR disclosure. This finding shows $\mathrm{H} 2$ was accepted. The frequency of audit committee meetings (ACMEET) shows a positive coefficient of 0.0076407 and is not significant $(\mathrm{t}=0.44)$. This means that the audit committee that often meets may not carry out their roles effectively and cannot increase CSR disclosure. This finding shows $\mathrm{H} 3$ was rejected. 
The control variable shows that company size has a positive and significant influence on corporate social responsibility disclosure. This means that the larger the size of the company will be more sensitive to engage in corporate governance disclosure practices (Nomran et al., 2018; Rahman and Bukair, 2013). Return on Assets (ROA) has a positive and insignificant effect, it is revealed that corporate social responsibility there is no influence with ROA. Auditor size of audit quality has a positive and insignificant effect due to the fact that public accounting firm of Big 5 does not affect to corporate social responsibility disclosure.

Table 4 is the results of the robustness test regression. In regression testing usually find things that are violated in testing classic assumptions. This test is carried out to reduce bias on the results of research and it is important to analyze the data affected by outliers and minimize the influence of outliers on the model so that the best model will be obtained. This finding is also strong with almost no difference with OLS regression.

Table 4. Results of Robust Regression

\begin{tabular}{lcccc}
\hline Vaviabel & \multicolumn{5}{c}{ Islamic Social Reporting } \\
\cline { 2 - 5 } & Coef. & Std. Err. & T & P>t \\
Robust & \multicolumn{5}{c}{ cons } & -1.499924 & 1.337703 & -1.12 & 0.268 \\
SSBSCORE & .1116696 & .089999 & 1.24 & 0.221 \\
ACSIZE & .1764261 & .0970801 & 1.82 & $0.075^{*}$ \\
ACMEET & .0076407 & .0183128 & 0.42 & 0.678 \\
FSIZE & .1417756 & .0444582 & 3.19 & $0.002^{* * *}$ \\
ROA & -1.14116 & 1.199641 & -0.95 & 0.346 \\
AQ & .0205017 & .1921935 & 0.11 & 0.915 \\
\hline N & 60 \\
F & 0.0019 & & \\
R & 0.4280 & & \\
\hline Years Dummies & Included \\
Source: (Data research, 2019)
\end{tabular}

\section{CONCLUSION}

Based on the analysis and discussion that has been discussed previously, then obtain three conclusions based on the framework research and. Hypothesis research results H1 denied SSB score will not affect, corporate social responsibility in particular on the company Syariah commercial banks in Indonesia. It means, characteristic of Syariah supervisory board Syariah banks not to be a determining factor for reporting. Corporate social responsibility research conducted research and is also supporting (Nugraheni \& Khasanah, 2019). The research results $h 2$ accepted. That means an audit committee size influential positive and significant. It means with a large number of the audit committee in the company can afford to keep tabs on the disclosure of corporate social responsibility, so that this can work effectively. The results showed that ACMEET denied H3, which means the company 
that frequency the meeting too often is not able to find a difference and make sure the reliability of CSR disclosure.

The results of the study are also supporting the research (Katmon et al., 2019). The results of variable control express its strongest in companies that had the size of the company that large having the disclosure of CSR to 360lamos probably the treble. Although there are obvious reasons, in companies that had ROA who high as well as AQ is a good one do not have the disclosure of CSR in which the high and have no influence significantly correlates with the disclosure of CSR.

\section{REFERENCE}

Appuhami, R., and Tashakor, S. (2017). The Impact of Audit Committee Characteristics on CSR Disclosure: An Analysis of Australian Firms. Australian Accounting Review, 27(4), 400-420. https://doi.org/10.1111/auar.12170.

Bédard, J., Chtourou, S. M., and Courteau, L. (2004). The Effect of Audit Committee Expertise, Independence, and Activity on Aggressive Earnings Management. Auditing, 23(2), 13-35. https://doi.org/10.2308/aud.2004.23.2.13.

Bereskin, F., Byun, S. K., Officer, M. S., and Oh, J. M. (2018, October 1). The Effect of Cultural Similarity on Mergers and Acquisitions: Evidence from Corporate Social Responsibility. Journal of Financial and Quantitative Analysis, Vol. 53, pp. 19952039. https://doi.org/10.1017/S0022109018000716.

Bicer, A. A., and Feneir, I. M. (2019). The Impact of Audit Committee Characteristics on Environmental and Social Disclosures: Evidence from Turkey. International Journal of Research in Business and Social Science, 8(3), 2147-4478. https://doi.org/10.20525/ijrbs.v8i3.262.

Birindelli, G., Ferretti, P., Intonti, M., and Iannuzzi, A. P. (2015). On the Drivers of Corporate Social Responsibility in Banks: Evidence from an Ethical Rating Model. Journal of Management and Governance, 19(2), 303-340. https://doi.org/10.1007/s10997-013-9262-9.

Che Azmi, A., Aziz, N. A., Non, N., and Muhamad, R. (2016). Sharia Disclosures: An Exploratory Study From The Perspective Of Sharia-Compliant Companies And Professional Users. Journal of Islamic Accounting and Business Research, 7(3), 237252. https://doi.org/10.1108/JIABR-03-2016-0029.

Clarkson, M. E. (1995). A Stakeholder Framework for Analyzing and Evaluating Corporate Social Performance. Academy of Management Review, 20(1), 92-117. https://doi.org/10.5465/amr.1995.9503271994.

Cornett, M. M., McNutt, J. J., and Tehranian, H. (2009). Corporate Governance and Earnings Management at Large U.S. Bank Holding Companies. Journal of Corporate Finance, 15(4), 412-430. https://doi.org/10.1016/j.jcorpfin.2009.04.003.

DeFond, M. L., and Francis, J. R. (2005). Audit Research after Sarbanes-Oxley. AUDITING: A Journal of Practice \& Theory, 24(s-1), 5-30. https://doi.org/10.2308/aud.2005.24.s-1.5.

Ernawan, K., and Daniel, D. R. (2019). The Influence of CEO Narcissism on Corporate Social Responsibility Disclosure. Jurnal Akuntansi, 23(2), 253-268. https://doi.org/10.24912/JA.V23I2.587.

Farook, S., Kabir Hassan, M., and Lanis, R. (2011). Determinants of Corporate Social 
Responsibility Disclosure: The Case of Islamic Banks. Journal of Islamic Accounting and Business Research, 2(2), 114-141. https://doi.org/10.1108/17590811111170539.

Fatoni, F., Andini, R., dan Raharjo, K. (2016). Pengaruh Kepemilikan Publik, Return On Equity, Current Ratio, Umur Perusahaan dan Company Size terhadap Pengungkapan Corporate Social Responbility pada Perusahaan Real Estate and Property Yang Terdaftar Di Bursa Efek Indonesia Periode 2011-2014. Retrieved November 7, 2019, from Journal Of Accounting website: http://jurnal.unpand.ac.id/index.php/AKS/article/view/454.

Fernández-Gago, R., Cabeza-García, L., and Nieto, M. (2018). Independent Directors' Background and CSR Disclosure. Corporate Social Responsibility and Environmental Management, 25(5), 991-1001. https://doi.org/10.1002/csr.1515.

Hameed, S., Mohamed, B., Ade, I., Bakhtiar, W., Mohd, A., Bin, N., Pramono, S. (2003). Alternative Disclosure \& Performance Measures for Islamic Banks.

Haniffa, R. M., and Cooke, T. E. (2002). Culture, Corporate Governance and Disclosure in Malaysian Corporations. Abacus, 38(3), 317-349. https://doi.org/10.1111/14676281.00112.

Hassan, A., and Syafri Harahap, S. (2010). Exploring Corporate Social Responsibility Disclosure: the Case of Islamic Banks. International Journal of Islamic and Middle Eastern Finance and Management, 3(3), 203-227. https://doi.org/10.1108/17538391011072417.

Jensen, M. C. (1993). The Modern Industrial Revolution, Exit, and the Failure of Internal Control Systems. The Journal of Finance, 48(3), 831-880. https://doi.org/10.1111/j.1540-6261.1993.tb04022.x.

Jizi, Mohammad Issam; Salama, Aly; Dixon, Robert; Stratling, R. (2014). Corporate Governance and Corporate Social Responsibility Disclosure: Evidence from the US Banking Sector. Retrieved November 6, 2019, from ProQuest website: https://search.proquest.com/docview/1627638203?pq-origsite=summon.

Kasali, R. (2006). Change! : Tak Peduli Berapa Jauh Jalan Salah Yang Anda Jalani, Putar Arah Sekarang Juga (Manajemen Perubahan Dan Manajemen Harapan). Jakarta Gramedia Pustaka Utama.

Katmon, N., Mohamad, Z. Z., Norwani, N. M., and Farooque, O. Al. (2019). Comprehensive Board Diversity and Quality of Corporate Social Responsibility Disclosure: Evidence from an Emerging Market. Journal of Business Ethics, 157(2), 447-481. https://doi.org/10.1007/s10551-017-3672-6.

Kent, P., and Stewart, J. (2008). Corporate Governance and Disclosures on the Transition to International Financial Reporting Standards. Accounting \& Finance, O(0), 080506173207474-??? https://doi.org/10.1111/j.1467-629X.2007.00257.x.

Khan, A., Muttakin, M. B., and Siddiqui, J. (2013). Corporate Governance and Corporate Social Responsibility Disclosures: Evidence from an Emerging Economy. Journal of Business Ethics, 114(2), 207-223. https://doi.org/10.1007/s10551-012-1336-0.

Khoirudin, A. (2013). Corporate Governance dan Pengungkapan Islamic Social Reporting pada Perbankan Syariah di Indonesia. Accounting Analysis Journal, 2(2). https://doi.org/10.15294/AAJ.V2I2.2919.

Li, J., Mangena, M., and Pike, R. (2012). The Effect of Audit Committee Characteristics on Intellectual Capital Disclosure. British Accounting Review, 44(2), 98-110. https://doi.org/10.1016/j.bar.2012.03.003. 
Mallin, C., Farag, H., and Ow-Yong, K. (2014). Corporate Social Responsibility And Financial Performance In Islamic Banks. Journal of Economic Behavior and Organization, 103. https://doi.org/10.1016/j.jebo.2014.03.001.

Mangena, M., and Pike, R. (2005). The Effect of Audit Committee Shareholding, Financial Expertise and Size on Interim Financial Disclosures. Accounting and Business Research, 35(4), 327-349. https://doi.org/10.1080/00014788.2005.9729998.

Nomran, N. M., Haron, R., \& Hassan, R. (2018). Shari'ah Supervisory Board Characteristics Effects On Islamic Banks' Performance: Evidence from Malaysia. International Journal of Bank Marketing, 36(2), 290-304. https://doi.org/10.1108/IJBM-12-2016-0197.

Nugraheni, P., and Khasanah, E. N. (2019). Implementation of the AAOIFI Index on CSR Disclosure in Indonesian Islamic Banks. Journal of Financial Reporting and Accounting, 17(3), 365-382. https://doi.org/10.1108/JFRA-02-2018-0013.

Omran, M. A., and Ramdhony, D. (2015). Theoretical Perspectives on Corporate Social Responsibility Disclosure: A Critical Review. International Journal of Accounting and Financial Reporting, 5(2). https://doi.org/10.5296/ijafr.v5i2.8035.

Othman, R., and Thani, A. M. (2010). Islamic Social Reporting Of Listed Companies In Malaysia Maqasid Shariah Model on Islamic Finance View project Islamic Social Reporting Of Listed Companies In Malaysia. International Business \& Economics Research Journal-April, 9(4). https://doi.org/10.19030/iber.v9i4.561.

Purwanto, A. (2011). Pengaruh Tipe Industri, Ukuran Perusahaan, Profitabilitas, terhadap Corporate Social Responsibility. Jurnal Akuntansi Dan Auditing, 8(1), 12-29. https://doi.org/10.14710/JAA.8.1.12-29.

Rahman, A. A., and Bukair, A. A. (2013). The Influence of The Shariah Supervision Board on Corporate Social Responsibility Disclosure By Islamic Banks of Gulf CoOperation Council Countries. Asian Journal of Business and Accounting, 6(2), 65105.

Suchman, M. C. (1995). Managing Legitimacy: Strategic and Institutional Approaches. Academy of Management Review, 20(3), 571-610. https://doi.org/10.5465/amr.1995.9508080331.

Wijaya, M. (2012). Pengaruh Kepemilikan Publik, Return On Equity, Current Ratio, Umur Perusahaan dan Company Size terhadap Pengungkapan Corporate Social Responbility pada Perusahaan Real Estate and Property Yang Terdaftar Di Bursa Efek Indonesia Periode 2011-2014. In Jurnal Ilmiah Mahasiswa Akuntansi (Vol. 1). 